\title{
ETHICAL COMMUNICATION IN PUBLIC RELATIONS
}

\author{
MSc. Luan Jahiri \\ PhD candidate, South East European University, North Macedonia \\ luan.jahiri@hotmail.com
}

\begin{abstract}
Ethics in relationships with the public today it relies on the codes of ethics that exist within all relevant institutions for public relations and public servants, which most often refer to moral principles such as honesty, integrity and not harming others. Ethical communication for an institution is seen as a good promoter of performance, because the ethical identity of the public servants, is very important for the public as well as for stakeholders for that institution. To define ethical communication of public servants, it is necessary to clearly understand the purpose of ethical communication, which refers to the practice of conveying honest information in a way that is not intended to be misleading. In other words, the information should be presented within a context that ensures that the information is not misleading as a result of being conveyed in a sort of vacuum. Ethical communication is fundamental to responsible thinking, decision-making, and the development of relationships and communities within and across contexts. Moreover, ethical communication enhances human worth and dignity by fostering truthfulness, fairness, responsibility, personal integrity, and respect for self and others. We do believe that unethical communication threatens the quality of all communication in public relations, and so the well-being of people and the society in which we live.
\end{abstract}

Keywords: public servants, performance, ethics, ethical communication, public relations.

\section{INTRODUCTION}

The modern concept of public servants implies that success is based on high ethical principles, ethical communication and professional norms and standards. In the face of a changing society many governments seem to keep doing things in the same old concept of work, and therefore in this paper will be analyzed ethical communication that should be applied in the professional practice of relationships with public in the world. The importance of this paper stems from the fact that it addresses the fact that every society should promote high moral demands on its individuals, so that they better understand why it is so necessary to communicate ethically. Encouraging a civic response against unethical behavior is imperative. The other issue that has to do with ethical communication is to understand the connection that it has with public relations, it must be clarified that it is not an abstract notion but is an important activity for the success of the state.

Public Relations is a discipline and profession that is constantly evolving, and in which perceptions of academic and professional ethical grounding are based on diametrically opposed positions. On the one hand, there are public perceptions that public relations are based on spin, manipulation and ethical resilience, while on the other hand, public relations theorists and public relations practitioners perceive it as the social, ethical and moral conscience of the organizations they represent. (Skinner, Mersham, Valin, (2003), Global protocol on ethics in public relations).

Ethical communication is the basic element of an administration, which for its humane and social nature has as its mission, the service with public relations. The service necessarily passes through real communication, but often also verbal but not directly such as the way from the outside but also the inner attitude that everyone holds in daily life in front of different people and situations. The administration is not only an entity in the service of another but also has the role of an educator and social informant for public relations. Through different ways of communication, the administration shares and transmits thoughts, feelings, emotions and support, based on the different problems and requests of citizens, as well as between persons working in the administration with special duties, officials working in public relations. (Mandelbaum, A. (2020), The Basic Principles Of Ethical Communication).

Ethics is not just what has become accepted within the practice itself. Just because something constantly doing the wrong thing doesn't mean it's desirable to do it again. 
ISSN 2661-2666 (Online) International Scientific Journal Monte (ISJM) DOI: $10.33807 /$ monte.20212034

Volume 5, (No).2 (2021): December

\section{OBJECTIVES}

There are many reasons why ethics, professionalism and ethical communication should characterize public relations practice, but equally important are characteristics and trust, social responsibility, balance of power and obligation, community building and conflict resolution. The point of public relations is to build and maintain relationships, and trust is crucial for this. It is important for the organization to be represented by someone ethical and professional.

Trust largely depends on the integrity of individual servants, so this is one of the reasons why public relations are under such a magnifying glass and why they are so powerful and influential. Public servants have an obligation to be as professional as possible. (Ralph Tench, Liz Yeoman (2009) Discovering public relations, pg.310)

Ethical issues and dilemmas are inherent in public relations, and their task is to ensure that public relations operate in accordance with ethics and ethical communication which is the basis of professionalism and credibility in the field. (Parson P.J. (2004) Ethics in Public Relations, A Guide to Best Practice, Kogan Page, pg. 2). Thus, we can conclude that the issue of ethics is one of the most common issues that "haunts" area of public relations.

According to Patricia J. Parson, the issue of ethics in public relations has become an oxymoron today due to the growing emergence of "spin", especially in the field of politics and economics. Doubt is more and more present the public - including employees, customers and consumers, etc. - who are very skeptical of to what they are told on a daily basis. We simply cannot afford to contribute more this type of mistrust, which brings us to the question: how important is ethics and ethical communication in relationships with public? (Parson P.J. (2004) Ethics in Public Relations, A Guide to Best Practice, Kogan Page, pg.23)

Public relations are limited by two regulatory frameworks. One is a legal and normative framework, and the other is a self-regulating, ethical framework. These two systems of norms and principles determine and regulate the "rules of the game" in the world of modern public communications. In this way, law and ethics define the normative environment in which public relations takes place and ensure compliance with the rules by all participants in public communication processes. In order to put legal issues in context, it is necessary to first understand the difference between "law" and "ethics" - "Fundamentally, law is a system of rules that governs a particular society. Ethics, on the other hand, involves decisions that people make in their private and professional lives. Individuals set ethical standards for their own behavior, some of which involve voluntary adherence to standards set by some professional groups". (Cutlip, S. M. Center, A. H., \& Broom, G. (2006) Effective Public Relations. Englewood Cliffs, NJ:Prentice-Hall).

\section{METHODOLOGY}

The modern concept of public relations implies that communication is based on high ethical principles and professional norms and standards, and therefore this paper will analyze the ethics of communication that should be applied in the professional practice of public relations. In order to answer other questions, we will use the survey method in our paper and content analysis, in order to examine the opinion of most often violated instructions from the code of ethics of public servants. How much manipulation and spins are present in the public are some of the questions to which we seek an answer through this paper?

The focus of the analysis will be on public servant's ethics, as a self-regulating framework of public communication, and this issue will be analyzed on a theoretical and practical level. On a theoretical level it will be analyzed utilitarian vision of communication ethics, deontological approach to ethics communication, the communication ethics of egalitarianism and relativism in ethics communication. As part of the analysis of communication ethics at the professional level will be analyzed codes of public relations ethics that create selfregulating frameworks of the public communication. Practical aspects of ethics will also be analyzed communication challenges, which are set before public relations employees.

A detailed analysis of the available materials will be made, regarding the regulation of ethics, ethical communication as well as the legal basis available for the regulation of labor relations in the Public Administration, the legal basis mainly based on the labor codes and regulations. internal administration and various public enterprises. These two concepts will be confronted with each other, in order to find out how far the law is implemented or not and how ethical the public administration is. An attempt for a normative approach through comparative analysis bringing it in two perspectives: traditional and explanatory considering that the factors that affect the construction and functioning of public administration. 
ISSN 2661-2666 (Online) International Scientific Journal Monte (ISJM) DOI: $10.33807 /$ monte.20212034

Volume 5, (No).2 (2021): December

The comparative analysis ${ }^{1}$ will examine the problems in public administration, ensuring uniformity in the improvement of law enforcement institutions and agencies. Consistency means that the current rules governing public sector activities and behavioral incentives are mutually supportive in the pursuit of efficient and accountable functioning.

\subsection{Data analysis - survey questionnaire}

- Questionnaire (Total: 151) - Valid 124 - Invalid 27

Is ethics something that executives and staff talk about regularly?

\begin{tabular}{|ll|l|l|l|l|}
\hline & Frequency & Percent & Valid Percent & Cumulative Percent \\
\hline Valid & None & 11 & 8.9 & 8.9 & 8.9 \\
Slightly & 23 & 18.5 & 18.5 & 27.4 \\
The average & 61 & 49.2 & 49.2 & 76.6 \\
To many & 18 & 14.5 & 14.5 & 91.1 \\
Extremely very much & 8 & 6.5 & 6.5 & 97.6 \\
I don't know & 3 & 2.4 & 2.4 & 100.0 \\
Total & 124 & 100.0 & 100.0 & \\
\hline
\end{tabular}

\begin{tabular}{|c|c|c|c|c|c|}
\hline & & Frequency & Percent & Valid Percent & Cumulative Percent \\
\hline \multirow[t]{7}{*}{ Valid } & None & 10 & 8.1 & 8.1 & 8.1 \\
\hline & Slightly & 15 & 12.1 & 12.1 & 20.2 \\
\hline & The average & 83 & 66.9 & 66.9 & 87.1 \\
\hline & To many & 8 & 6.5 & 6.5 & 93.5 \\
\hline & Extremely very much & 2 & 1.6 & 1.6 & 95.2 \\
\hline & I don't know & 6 & 4.8 & 4.8 & 100.0 \\
\hline & Total & 124 & 100.0 & 100.0 & \\
\hline
\end{tabular}

What about Communication skills of colleagues?

\begin{tabular}{|ll|l|l|l|l|}
\hline & Frequency & Percent & Valid Percent & Cumulative Percent \\
\hline Valid & None & 4 & 3.2 & 3.2 & 3.2 \\
Slightly & 20 & 16.1 & 16.1 & 19.4 \\
The average & 45 & 36.3 & 36.3 & 55.6 \\
To many & 44 & 35.5 & 35.5 & 91.1 \\
Extremely very much & 11 & 8.9 & 8.9 & 100.0 \\
I don't know & 124 & 100.0 & 100.0 & \\
\hline
\end{tabular}

\footnotetext{
${ }^{1}$ The method of comparative analysis is about weighing comparative elements, common features or differences that have two or more phenomena, events, objects, etc.
} 
ISSN 2661-2666 (Online) International Scientific Journal Monte (ISJM) DOI: $\underline{10.33807 / m o n t e .20212034}$

Volume 5, (No).2 (2021): December

In what areas do you consider staff training most needed?

\begin{tabular}{|ll|l|l|l|l|}
\hline & Frequency & Percent & Valid Percent & Cumulative Percent \\
\hline Valid $\quad$ Customer behavior & 96 & 77.4 & 77.4 & 77.4 \\
& Responsibilities at work & 28 & 22.6 & 22.6 & 100.0 \\
& Total & 124 & 100.0 & 100.0 & \\
\hline
\end{tabular}

\section{RESULTS}

The paper seeks to point out the continuity of ethical problems and dilemmas in public relations from their founding to the present day and to reach a possible ethical framework for access to this activity. After a brief description of the definitions and development of the profession of public relations and a presentation of the basic assumptions of recent theories of ethics in it, after the survey questionnaire results, we then judge their approach to ethics and compare it with recent approaches to ethics in public relations and we draw conclusions:

We recognize the continuity of doubts between two fundamentally different approaches to ethics in public relations, from its founding to the present day and the need for a unique and clear ethical framework for decision-making in this field. The public expects more from public servants' professional behavior and good communication, but the image of public relations as a profession is often unfairly negative due to the unprofessional and unethical conduct of individuals within the profession. The ethical opinion of public relations professional's ranges from dilemma: whatever you want people to do to you, do to them; to professional loyalty to the company or organization they work for. In order to prevent and sanction unethical phenomena, it is important to set rules in the form of codes according to which public relations experts will adjust their behavior and do more training for the servants.

People are skeptical of the information they receive from communication of public servants. They are less and less sure that the information they receive is really there to inform them, and more and more they believe that it was released for the purpose of manipulating public opinion. As for the opinion of experts, we can see that they also state that ethics is a matter of the individual and that even if this unethicalness appears, the most common cause is that individual to whom it is important to say something different from the real truth at that moment. It will take a lot of reform and even more time for people to start believing what is being offered to them as information and to start looking at it again as information rather than as a means of manipulating and making it easier to reach a goal.

As expected, results from this paper tell us that although much has been done to have ethical communication in public relations, it is still not enough. It is important that ethics is understood by all people in order to understand when a behavior is or is not ethical and to act ethically. There are many definitions of ethics, but the generalities in work, communication and life should be: Doing and talking what is right; It is the goal of a good life, with and for the other, within righteous institutions. It does not matter which of these definitions everyone prefers, but it is important to understand and act on it, acting right and achieving the right performance. So, to be ethical and speak ethical you must act in a fair, honest way, considering the consequences and responsibilities etc. Ethical behavior and communication are important, if you want to succeed, you must be guided by this principle. Drafting codes and ethical procedures are very vital for advancing ethical issues in an organization, if these do not exist then no one can be guided. All civil servants must act accurately towards the good and the right.

In order to have performance and success, an organization must respect ethics in services and communication. Ethics in public service is about the practical application of moral standards in governance. (Chapman, R. (2002), "Ethics in public service for the new millennium", pg. 210). Ethics relates first and foremost to the way the individual feels about how he should behave; it is about values and their application in each context. It is known that civil society is directly related to the service provided by the public administration and as a result it orients its entire activity towards meeting the needs and interests in the public relations, exercising its functions, based on sound ethical principles and respect for the law. It is very important to develop high moral awareness in administration officials who communicate with individuals representing different social groups with in public relations. (Menzel, D. C, (2005), "Research on Ethics and Integrity in Governance: A Review and Assessment" Published by Northern Illinois University in the March, issue of Public Integrity, p. 10). 
ISSN 2661-2666 (Online) International Scientific Journal Monte (ISJM) DOI: 10.33807/monte.20212034

Volume 5, (No).2 (2021): December

\section{CONCLUSIONS}

If ethics is the science of morality, and morality is the understanding of the concepts of good and evil, then ethics in relationships would with the public has to be: how to set up and by what means to use according to good or bad public opinion, without at the same time underestimating, insulting or belittling that public. For success and communication with the public, ethics of public servants must include values such as honesty, openness, loyalty, synonymy, respect, integrity and honest communication. This definition of ethics in public relations is far away is from the practice that Grunig and Hunt wrote about in terms of the term "flacking for space" $(1984, \mathrm{pg}$. 30) which these two authors explain in a way that there has been a constant effort by servants in relationships with the public to get information for the client where they used everything possible tricks to take advantage of the media or spin messages with persuasion techniques. (D.Bowen A.S.(2007) Ethics and Public Relations", pg. 30).

During the research of this topic, it was proved that:

Very few principles of joint governance in public relations have been followed, organizations have their own codes of conduct named as Internal Regulations but not Codes of Ethics; For organizations to be successful, employees must work honestly, they must have integrity, but they must also build trust, both with colleagues, managers and customers; Ethical behavior and communication should not be the pursuit of our feelings, ethical behavior and communication is not a matter of religion or law, but it is an obligation to work, it is an obligation to the requirements of society, we must have principles regarding ethical behavior and communication ethical, so we should behave at work as we behave at home and with the family, as if the work we do is a private business.

The following recommendations emerge from these conclusions:

Governmental and non-governmental organizations should train staff continuously with training - Customer Behavior; Every Governmental and non-governmental organization should have Codes of Ethics, these codes which define all working principles; Public organizations should define the duties and responsibilities to the staff, based on the education they have and the continuous behaviors they have at work; Every organization should have impartiality in staff management, management staff should have human moral attributes; Management and staff should be a common segment for the success of the organization, staff should always be motivated to achieve the objectives of the organization; So, for organizations to be SUCCESSFUL, all staff must have RESPECT and RESPONSIBILITY in the work end communication that they perform.

The modern concept of public relations implies that communication is based on high ethical principles and standards. Ethical conduct is a prerequisite for any communication and thus that which organizations conduct with the public relations. When it comes to professional communication that is subject to strict criteria of business ethics, and ethical codes that it has every profession. Public relations are particularly sensitive to ethical respect principles and codes in work, because the reputation of the entire organization depends on it. Experts for public relations all over the world, must know the theoretical postulates but also the ways of practical application of ethical principles, standards and codes, when communicating with its strategic publics.

In the end of this paper, we can say that public communicators, who want to establish and maintain successful relationships with their strategic publics they need to know, understand and respect the two regulatory frameworks: normative-legal and ethical. Normative-legal framework, which includes international conventions, constitutional provisions and legal solutions, represents the basis on which public communication and public relations are based into the modern world. However, the normative-legal framework is, basically, only the first a step towards the complete regulation of the public relation profession, because without knowledge, understanding and application of ethical principles and codes of applied public relation ethics, cannot even be successful public relations. Based on the analysis, it is clear that the ethics of communication represents reference framework and platform for self-regulation of public relations. 
ISSN 2661-2666 (Online) International Scientific Journal Monte (ISJM) DOI: 10.33807/monte.20212034

Volume 5, (No).2 (2021): December

\section{REFERENCES}

\section{BOOKS:}

1. Chapman, R. (2002), "Ethics in public service for the new millennium", Iceberg Publications, Tirana;

2. Kocani, A. (2005), "Introduction to Epistemology”, SHLBU, Tirana;

3. Dobjani, E., (2007), “Administrative Law”, Perlat Voshtina, Tirana;

4. Menzel, D. C, (2005), "Research on Ethics and Integrity in Governance: A Review and Assessment” Published by Northern Illinois University in the March, issue of Public Integrity;

5. Tench R., Yeomans L. (2009), "Discovering Public Relations", Print Library, Zagreb;

6. Parson PJ. (2004\&2008), "Ethics in Public Relations: A Guide to Best Practice", Kogan Page Limited, London and Philadelphia;

7. Cutlip\&Center. (2012), "Effective Public Relations", Prentice Hall, New Jersey.

\section{ARTICLES:}

8. University of Madrid, publication (2005)

Available at: https://e-archivo.uc3m.es/handle/10016/144\#preview accessed 15.01.2021;

9. BOWEN AS, Ethics and Public Relations, IPR Syracuse University,

Available at: https://instituteforpr.org/ethics-and-public-relations/ accesed 18.02.2021;

10. Potter W, Does «Ethical PR» HAVE to be an Oxymoron, Richard Edelman?, PR WATCH, Available at: http://www.prwatch.org/node/9650 accesed 10.03.2021. 